\title{
SUPPORT SERVICES FOR CERAMIC FIBER-CERAMIC MATRIX COMPOSITES
}

Annual Technical Progress Report

December 27, 1996

Report Prepared by

John P. Hurley and Jan W. Nowok

Energy \& Environmental Research Center

University of North Dakota

PO Box 9018

Grand Forks, ND 58202-9018

under

$19 a-S S 112 \mathrm{~V}$

for

OAK RIDGE NATIONAL LABORATORY

Oak Ridge, Tennessee 37831

Managed by

LOCKHEED MARTIN ENERGY RESEARCH CORP.

for the

U.S. DEPARTMENT OF ENERGY

under Contract No. DE-AC05-96OR22464

NASTFIBUTGH OF THS IOUUMENT IS UNLMTED 


\section{DISCLAIMER}

Portions of this document may be illegible in electronic image products. Images are produced from the best available original document. 


\section{DISCLAIMER}

This report was prepared as an account of work sponsored by an agency of the United States Government. Neither the United States Government nor any agency thereof, nor any of their employees, make any warranty, express or implied, or assumes any legal liability or responsibility for the accuracy, completeness, or usefulness of any information, apparatus, product, or process disclosed, or represents that its use would not infringe privately owned rights. Reference herein to any specific commercial product, process, or service by trade name, trademark, manufacturer, or otherwise does not necessarily constitute or imply its endorsement, recommendation, or favoring by the United States Government or any agency thereof. The views and opinions of authors expressed herein do not necessarily state or reflect those of the United States Government or any agency thereof. 


\section{SUPPORT SERVICES FOR CERAMIC FIBER-CERAMIC MATRIX COMPOSITES}

Annual Technical Progress Report

December 27, 1996

Research Sponsored by the U.S. Department of Energy

Office of Fossil Energy

Advanced Research and Technology Development Materials Program

Report Prepared by

John P. Hurley and Jan W. Nowok

Energy \& Environmental Research Center

University of North Dakota

PO Box 9018

Grand Forks, ND 58202-9018

under

19a-SS112V

for

OAK RIDGE NATIONAL LABORATORY

Oak Ridge, Tennessee 37831

Managed by

LOCKHEED MARTIN ENERGY RESEARCH CORP.

for the

U.S. DEPARTMENT OF ENERGY

under Contract No. DE-AC05-96OR22464 
This report has been reproduced directly from the best available copy.

Available to DOE and DOE contractors from the Office of Scientific and Technical Information, PO Box 62, Oak Ridge, TN 37831; prices available from (423) 576-8401.

Available to the public from the National Technical Information Service, U.S. Department of Commerce, 5285 Port Royal Road, Springfield, VA 22161.

This report was prepared as an account of work sponsored by an agency of the United States Government. Neither the United States Government nor any agency thereof, nor any of their employees, makes any warranty, expressed or implied, or assumes any legal liability or responsibility for the accuracy, completeness, or usefulness of any information, apparatus, product, or process disclosed or represents that its use would not infringe privately owned rights. Reference herein to any specific commercial product, process, or service by trade name, trademark, manufacturer, or otherwise, does not necessarily constitute or imply its endorsement, recommendation, or favoring by the United States Government or any agency thereof. The views and opinions of authors expressed herein do not necessarily state or reflect those of the United States Government or any agency thereof. 


\section{TABLE OF CONTENTS}

LIST OF FIGURES $\ldots \ldots \ldots \ldots \ldots \ldots \ldots \ldots \ldots \ldots \ldots \ldots \ldots \ldots \ldots$

LIST OF TABLES $\ldots \ldots \ldots \ldots \ldots \ldots \ldots \ldots \ldots \ldots \ldots \ldots \ldots \ldots$

1.0 INTRODUCTION $\ldots \ldots \ldots \ldots \ldots \ldots \ldots \ldots \ldots \ldots \ldots \ldots \ldots \ldots \ldots$

2.0 FACTORS AFFECTING THE COMPOSITION OF ASH DEPOSITS $\ldots \ldots \ldots \ldots$

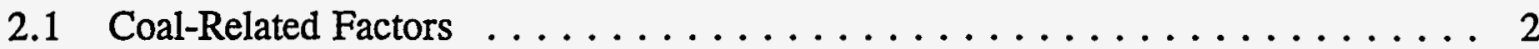

2.2 Factors Related to Ash Deposition Mechanisms . . . . . . . . . . . . 2

2.3 Factors Related to the Temperature of the Material . . . . . . . . . . . . 3

3.0 CORROSIVE CONDITIONS IN GASIFICATION SYSTEMS $\ldots \ldots \ldots \ldots \ldots$

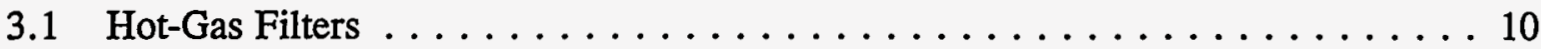

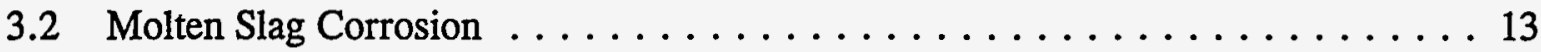

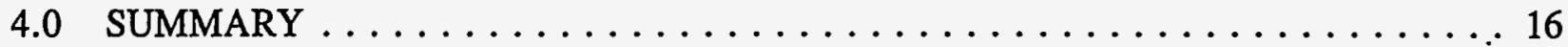

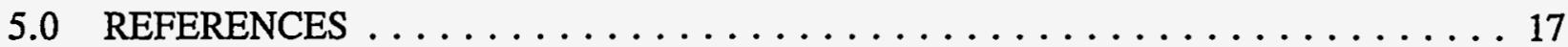




\section{LIST OF FIGURES}

1 Comparison of the compositions $\left(\mathrm{SO}_{3}\right.$-free) of aerodynamically sized entrained ash particles

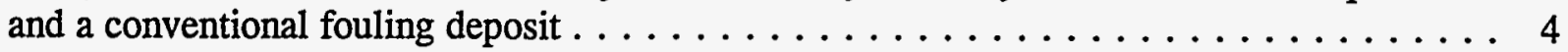

2 Comparison of the compositions $\left(\mathrm{SO}_{3}\right.$-free) of aerodynamically sized entrained ash particles and an upstream enamel deposit $\ldots \ldots \ldots \ldots \ldots \ldots \ldots \ldots \ldots \ldots \ldots \ldots \ldots$

3 Temperature-dependent concentrations of silicon, sulfur, and calcium (reported as oxides) in deposits collected from the convective pass of a pulverized coal-fired utility boiler burning a subbituminous coal from the western United States . . . . . . . . . . . . . 5

4 Temperature-dependent concentrations of sodium, potassium, and phosphorus (reported as oxides) in deposits collected from the convective pass of a pulverized coal-fired utility boiler burning a subbituminous coal from the western United States $\ldots \ldots \ldots \ldots \ldots$

5 Viscosity-versus-temperature plot for a slag produced in a boiler firing Illinois No. 6 bituminous coal to which limestone has been added to reduce slag viscosity $\ldots \ldots \ldots$

6 Scanning electron micrograph of a cross section of Hexoloy SA silicon carbide (bottom) exposed to Illinois No. 6 slag (top) at $2300^{\circ} \mathrm{F}$ in a static slag corrosion test in air . . . . . 7

7 Scanning electron micrograph of the interface between siliconized silicon carbide (bottom) and a high-calcium ash doped with excess sodium sulfate (top) reacted at $1790^{\circ} \mathrm{F} \ldots \ldots$

8 The calculated concentrations of major vapor-phase chloride species in the fluid bed of the Piñon Pine system as a function of the chlorine content of the coal $\ldots \ldots \ldots \ldots$

9 Viscosity versus temperature for Rochelle mine coal ash slag under three atmospheres . . . 15 


\section{LIST OF TABLES}

1 Coal Ash Chemical Composition Ranges $\ldots \ldots \ldots \ldots \ldots \ldots \ldots \ldots \ldots \ldots \ldots$

2 Typical Operating Conditions for the Main Types of Oxygen-Blown Gasifiers . . . . . . . 11

3 Calculated Partial Pressures of Minor Corrodent Gas Species in the Piñon Pine System . . 12

4 TRDU Filter Ash Ultimate-Proximate Analysis . . . . . . . . . . . . . 14

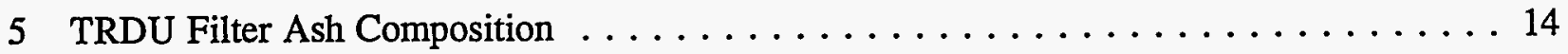

6 TRDU Filter Ash Crystalline Composition . . . . . . . . . . . . . . 15

7 Chemical Compositions of Standard Ashes . . . . . . . . . . . . 16 


\section{SUPPORT SERVICES FOR CERAMIC FIBER-CERAMIC MATRIX COMPOSITES}

Research sponsored by the U.S. Department of Energy, Fossil Energy Advanced Research and Technology Development Materials Program, DOE/FE AA 151010 0, Work Breakdown Structure Element UNDEERC-4

\subsection{INTRODUCTION}

Many advanced power systems will combine two energy cycles to reach efficiencies as high as $47 \%$ in converting the chemical energy in coal into electrical energy. One energy cycle is always a typical steam, or Rankine, cycle, which usually produces $60 \%-80 \%$ of the electric power. The second cycle usually involves one of three other methods of firing a turbine. The method used in pressurized fluidized-bed combustion (PFBC) is to remove the particulate from the hot flue gas with a high-temperature filter, then directly expand the cleaned gas in a gas turbine. In another concept, the turbine is indirectly fired by using a very high-temperature heat exchanger to transfer the energy to a clean noncondensing working fluid, such as air, which is then expanded in the turbine. The third possibility is to gasify the coal, clean the coal gas, then fire the gas directly into a gas turbine. A steam cycle combined with a gasification cycle is commonly called an integrated gasification combined cycle (IGCC).

Ceramics, or advanced, alloys are suggested for construction of subsystems in power plants employing these energy cycles because of their resistance to corrosion and their high-temperature strength. Dense structural ceramics are proposed for use in heat exchangers, which may be used at temperatures as high as $1425^{\circ} \mathrm{C}$. Both monolithic and composite ceramics and advanced alloys such as iron aluminide are used to construct hot-gas filters to remove ash from the gas stream at temperatures up to $900^{\circ} \mathrm{C}$. To encourage the acceptability of these subsystems, a better understanding of the long-term performance of the materials is required.

The University of North Dakota Energy \& Environmental Research Center (EERC) is providing technical assistance and test materials to the U.S. Department of Energy (DOE) Advanced Research and Technology Development (AR\&TD) Materials Program investigating ceramic and advanced alloy corrosion in fossil energy systems. During 1995-1996, suggestions were developed and ash was collected for testing the corrosion resistance of materials in air-blown fluidized-bed gasification systems such as the Sierra Pacific Power Company Piñon Pine Project. Descriptions of these activities are presented in this report, which is an extension of a technical paper entitled "Conditions for Testing the Corrosion Rates of Ceramics in Coal Gasification Systems" (1) which was prepared and presented at the 10th Annual Fossil Energy Materials Conference in Oak Ridge, Tennessee, as one of the deliverables of this project. Section 2.0 of this report, providing a background, was first presented in last year's final report (2). It is included here to make this report more accessible to the materials scientist who does not have an extensive background in fossil energy systems.

\subsection{FACTORS AFFECTING THE COMPOSITION OF ASH DEPOSITS}

All surfaces of a coal-fired combustor upstream of particulate removal systems become covered with ash. The composition of the ash deposits depends on the composition of the coal, the mechanisms of ash deposition, and the temperature of the deposits. 


\subsection{Coal-Related Factors}

Coal is composed primarily of carbon, with lesser amounts of heteroatoms such as hydrogen, oxygen, sulfur, and nitrogen and ash-forming constituents such as mineral matter and organically associated alkali and alkaline-earth cations. The quantity and form of the major elements in the coal are determined by the original plants, the depositional environment, and the interaction of the buried material with groundwater before and after coalification.

Coals from the eastern United States are typically high-rank coals that form ash from mineral grains. The most prevalent minerals in U.S. coals are quartz $\left(\mathrm{SiO}_{2}\right)$, kaolinite $\left(\mathrm{Al}_{2} \mathrm{Si}_{2} \mathrm{O}_{5}[\mathrm{OH}]_{4}\right)$ and other aluminosilicate clays such as montmorillonite $\left([\mathrm{Al}, \mathrm{Mg}]_{8}\left[\mathrm{Si}_{4} \mathrm{O}_{10}\right]_{3}[\mathrm{OH}]_{10} \cdot 12 \mathrm{H}_{2} \mathrm{O}\right)$ and illite, $\left(\mathrm{KAl}_{5} \mathrm{Si}_{7} \mathrm{O}_{20}[\mathrm{OH}]_{4}\right)$, and pyrite $\left(\mathrm{FeS}_{2}\right)$. These minerals are rich in silicon, aluminum, and iron so the coal ash is acidic. Coals from the western United States also contain these minerals, but they are primarily lower-rank coals that have undergone less lithification than the eastern coals and so contain much more oxygen in their organic structures. The oxygen is commonly present in carboxylic acid functional groups. During interaction with groundwater, these acids can undergo ion exchange to fix sodium, potassium, magnesium, and calcium in an atomically dispersed form within the organic structure. The addition of the alkali metal and alkaline-earth elements to the ash make it much more basic than eastern coal ash.

Because of the large range of depositional environments, degrees of coalification, and interactions with groundwater, U.S. coal ashes have a wide range of compositions. Table 1 shows the range as given in a standard text (3). This wide range of compositions requires the materials researcher to consider specific coals that may be used in the energy system of interest.

\section{TABLE 1}

Coal Ash Chemical Composition Ranges

\begin{tabular}{lc}
\hline Oxide Component & Percentage \\
\hline $\mathrm{SiO}_{2}$ & $10-70$ \\
$\mathrm{Al}_{2} \mathrm{O}_{3}$ & $8-38$ \\
$\mathrm{Fe}_{2} \mathrm{O}_{3}$ & $2-50$ \\
$\mathrm{CaO}$ & $0.5-30$ \\
$\mathrm{MgO}$ & $0.3-8$ \\
$\mathrm{Na}_{2} \mathrm{O}$ & $0.1-8$ \\
$\mathrm{~K}_{2} \mathrm{O}$ & $0.1-3$ \\
$\mathrm{SO}_{3}$ & $0.1-30$ \\
\hline
\end{tabular}

\subsection{Factors Related to Ash Deposition Mechanisms}

In addition to the type of coal that may be used in the energy system, the experimentalist must consider which fractions of the ash will come into contact with the ceramic. This information is best obtained experimentally, although approximations can be made based on extensive testing 
performed at utility boilers. During combustion of the coal, the minerals can vaporize, fragment, or coalesce, depending on the initial association of the mineral with the coal, the temperature and gas composition of the local combustion environment, and the morphology of the original mineral grains (4-9). In general, mineral grains that are included within coal particles will experience temperatures $200^{\circ}-300^{\circ} \mathrm{C}$ higher and much more reducing conditions than the excluded mineral grains that are separate from the carbonaceous particles. The included minerals commonly fuse with other mineral grains in the particle to form larger, more compositionally complex ash particles. The excluded mineral grains are much less likely to interact with other mineral grains. They are also more likely to fragment to form smaller ash particles.

In contrast to the mineral grains, the organically associated elements vaporize during combustion and become extremely reactive. The alkaline-earth elements rapidly oxidize to form micron-sized ash particles on the surface of the burning char particle. These can be shed as oxide particles or coalesce with quartz- and clay-derived ash to form complex aluminosilicates $(4,5)$. In contrast, the vaporized alkali metals exist as gaseous sulfates, hydroxides, and chlorides that can condense far downstream of the fireball. The vaporization and subsequent condensation of the organically associated elements cause them to become enriched in smaller ash particles.

The size and composition interdependence in the ash sometimes causes the composition of the ash depositing on the structure of interest to be very different from that of the bulk ash. This occurs because the size of ash that forms the deposits depends on the local gas flow conditions. For example, if the structure of interest is a tube placed directly in the gas flow, then larger ash particles will separate from the gas flow and strike the tube as the gas diverges around it, while the smaller ash will stay entrained with the gas. Figure 1 illustrates this concept. It compares the compositions of a conventional ash fouling deposit formed at $2100^{\circ} \mathrm{F}$ on the upstream side of a steam tube with four aerodynamic size ranges of particulate ash collected from the boiler at the same location (10). The boiler was firing a high-calcium subbituminous coal at the time. The bulk composition of the deposit shows that it is formed primarily from particles with aerodynamic diameters of over $10 \mu \mathrm{m}$. The most striking variations in elemental concentration versus ash particle size occur for silicon and calcium. The average concentration of silicon in the ash particles is much greater in the larger particles, whereas the average concentration of calcium is much greater in the smaller particles. This relationship is typical of most high-calcium U.S. coals.

Figure 2 shows the compositions of another type of ash deposit along with aerodynamically sized ash collected in the vicinity. This type of deposit forms an enamel-like coating on the upstream sides of steam tubes when high-calcium coals are fired. It typically forms at temperatures below approximately $1700^{\circ} \mathrm{F}$. A comparison of the compositions shows that these deposits form predominantly from particles with aerodynamic diameters below $3 \mu \mathrm{m}$ and so are greatly enriched in calcium and depleted in silicon compared to the higher-temperature deposits. Materials prone to calcium corrosion would be much more severely attacked by this type of deposit than by the first. In addition, Figure 2 shows that the deposit contains a high level of sulfur and that the sulfur condenses after ash deposition. The sulfur also can be quite corrosive, especially to alloys.

\subsection{Factors Related to the Temperature of the Material}

The temperature of the subsystem affects not only the kinetics of reaction but the composition and physical nature of the ash deposit as well. Figure 3 shows the concentrations of silicon, 


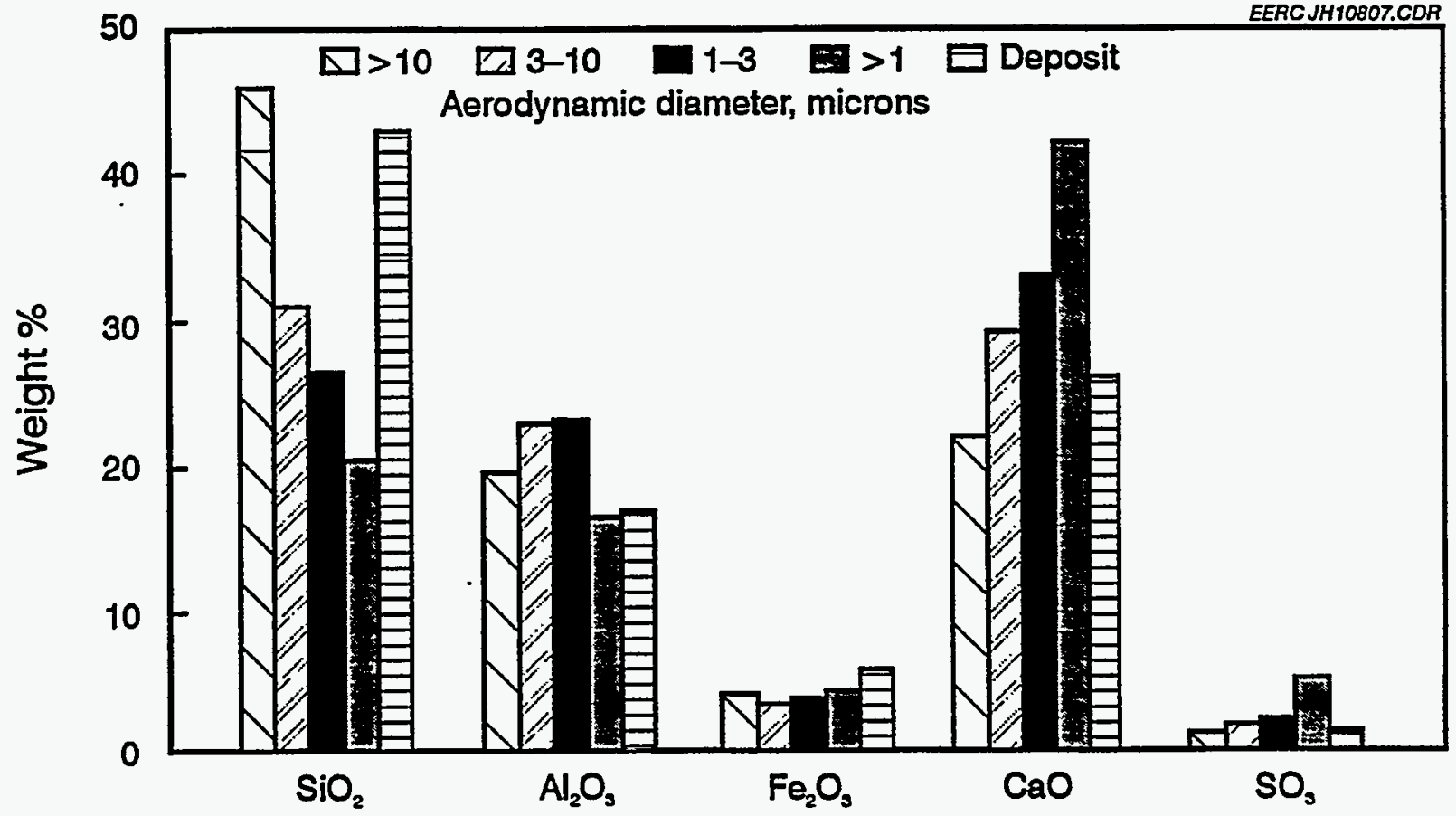

Figure 1. Comparison of the compositions $\left(\mathrm{SO}_{3}\right.$-free) of aerodynamically sized entrained ash particles and a conventional fouling deposit.

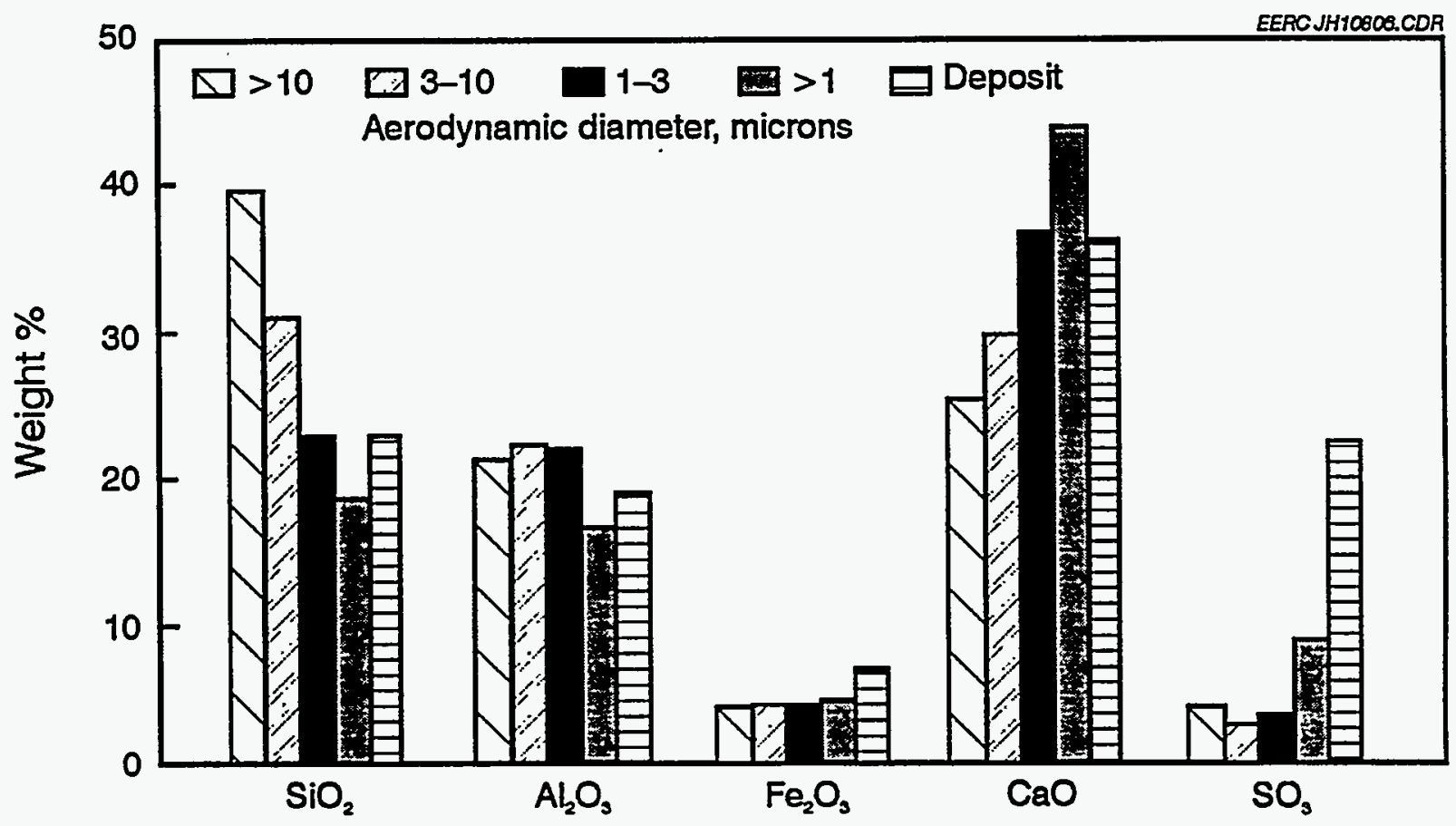

Figure 2. Comparison of the compositions ( $\mathrm{SO}_{3}$-free) of aerodynamically sized entrained. ash particles and an upstream enamel deposit. 


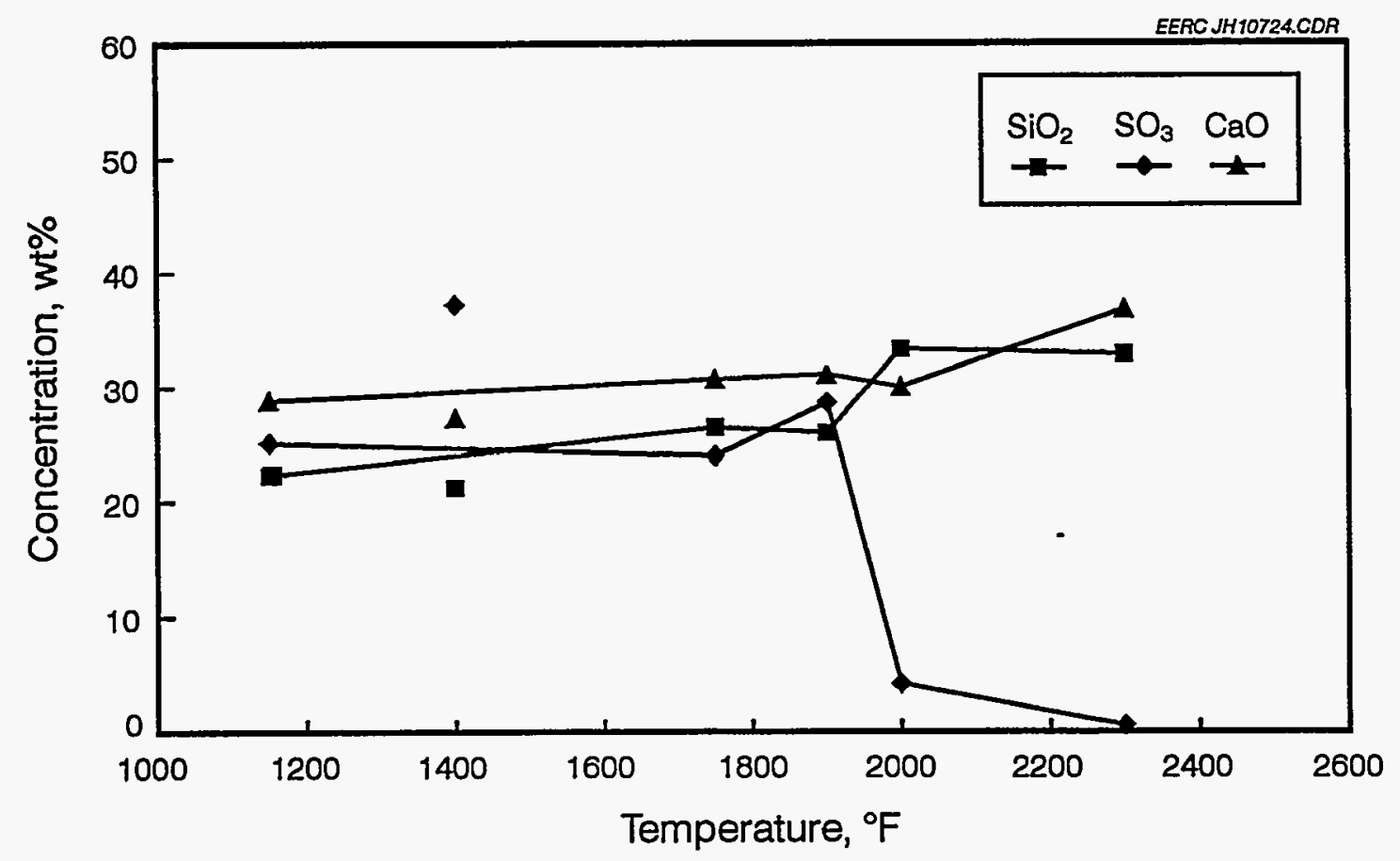

Figure 3. Temperature-dependent concentrations of silicon, sulfur, and calcium (reported as oxides) in deposits collected from the convective pass of a pulverized coal-fired utility boiler burning a subbituminous coal from the western United States.

calcium, and sulfur in ash deposits collected from steam tubes in a boiler firing a high-calcium coal. It shows that the sulfur concentration in the deposits increases dramatically at temperatures below $2000^{\circ} \mathrm{F}$. Laboratory experiments show that the mechanism of increase is chemical vapor deposition caused by the conversion of calcium in either oxides or aluminosilicates to calcium sulfate below $1900^{\circ} \mathrm{F}$. Figure 4 shows the concentrations of sodium, potassium, and phosphorus in the same deposits. They also increase significantly, but not as much as that of the sulfur. The sodium concentration increases primarily through physical vapor deposition, or condensation, of sodium sulfate. This indicates that in the presence of ash, materials cooled to below approximately $1900^{\circ} \mathrm{F}$ will be subjected to alkali sulfate corrosion, whereas those at higher temperatures will not. This may be especially prevalent for heat exchangers operating at gas temperatures above $1900^{\circ} \mathrm{F}$ but with surface temperatures below.

In addition to affecting composition, temperature will affect the physical nature of the deposits. Figure 5 shows a viscosity-versus-temperature plot for fused slag formed in the Central Illinois Public Service Coffeen Plant boiler while burning Illinois No. 6 bituminous coal to which limestone has been added to reduce the viscosity of the slag. The measurements were made in air and in a reducing environment in the presence of $10 \%$ water vapor. At temperatures above $2500^{\circ} \mathrm{F}$, the slag has a viscosity below 250 poise and so will be erosive as well as corrosive. These liquid slags dissolve the protective oxide scale on most ceramic materials, causing the corrosion rate to be 


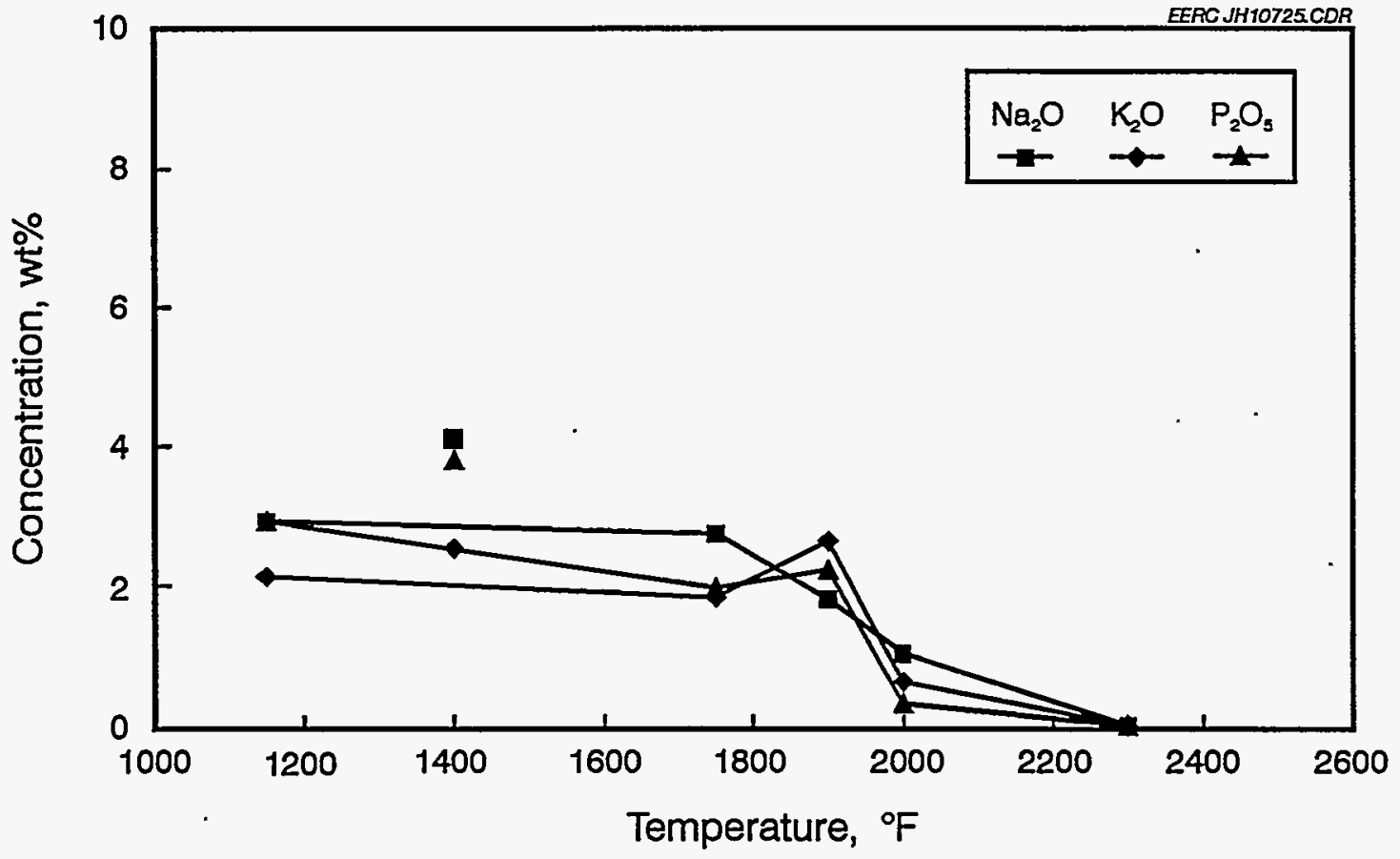

Figure 4. Temperature-dependent concentrations of sodium, potassium, and phosphorus (reported as oxides) in deposits collected from the convective pass of a pulverized coal-fired utility boiler burning a subbituminous coal from the western United States.



Figure 5. Viscosity-versus-temperature plot for a slag produced in a boiler firing Illinois No. 6 bituminous coal to which limestone has been added to reduce slag viscosity. 
linear rather than parabolic with time. Corrosion by flowing slag is expected to result in a uniform recession rate of the surface, rather than the pitting that is seen in static slag or with sintered ash. Figure 6 is a scanning electron micrograph of a cross section of Hexoloy SA silicon carbide exposed to another Illinois No. 6 slag at $2300^{\circ} \mathrm{F}$ in a static corrosion test performed in air (11). The bright spheres are composed of iron silicide that is often found near pits in the silicon carbide. The pitting may weaken the material, although the recession rate is reduced as compared to flowing slag corrosion.

At still lower temperatures, the ash may sinter but does not dissolve the protective oxide layer. Figure 7 is a scanning electron micrograph of the interface between siliconized silicon carbide (bottom) and a fine high-calcium ash doped with excess sodium sulfate (top) and reacted in air at $1790^{\circ} \mathrm{F}(12)$. Scanning electron microscopy (SEM) analyses show that the scale is composed of calcium and magnesium silicate. Only very low levels of sodium could be measured in the scale, but similar experiments performed without the condensed sodium sulfate (but with the vapor) show that the oxidation rate of the material is greatly increased by the presence of the sodium. Sodium silicate does not form extensively in this situation because it is not stable in the presence of aluminosilicate ash.

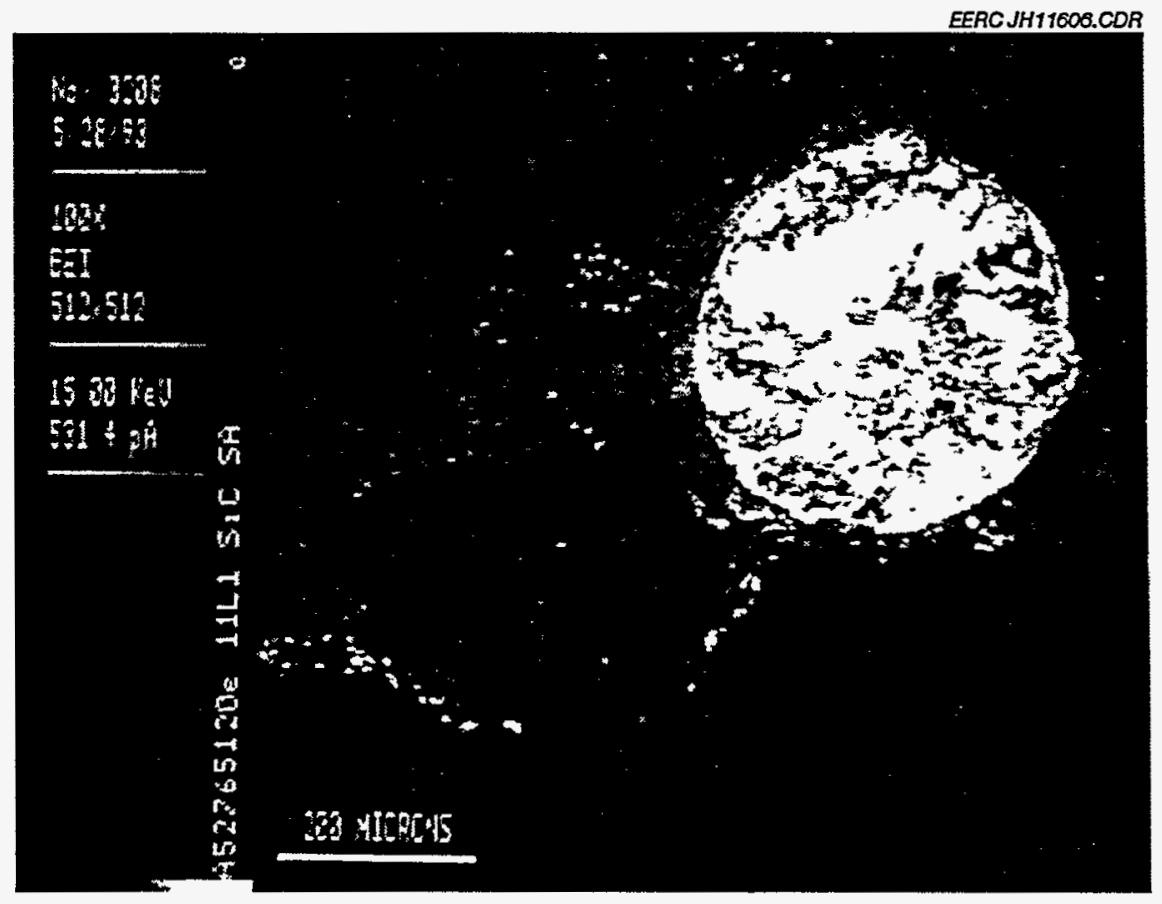

Figure 6. Scanning electron micrograph of a cross section of Hexoloy SA silicon carbide (bottom) exposed to Illinois No. 6 slag (top) at $2300^{\circ} \mathrm{F}$ in a static slag corrosion test in air. 


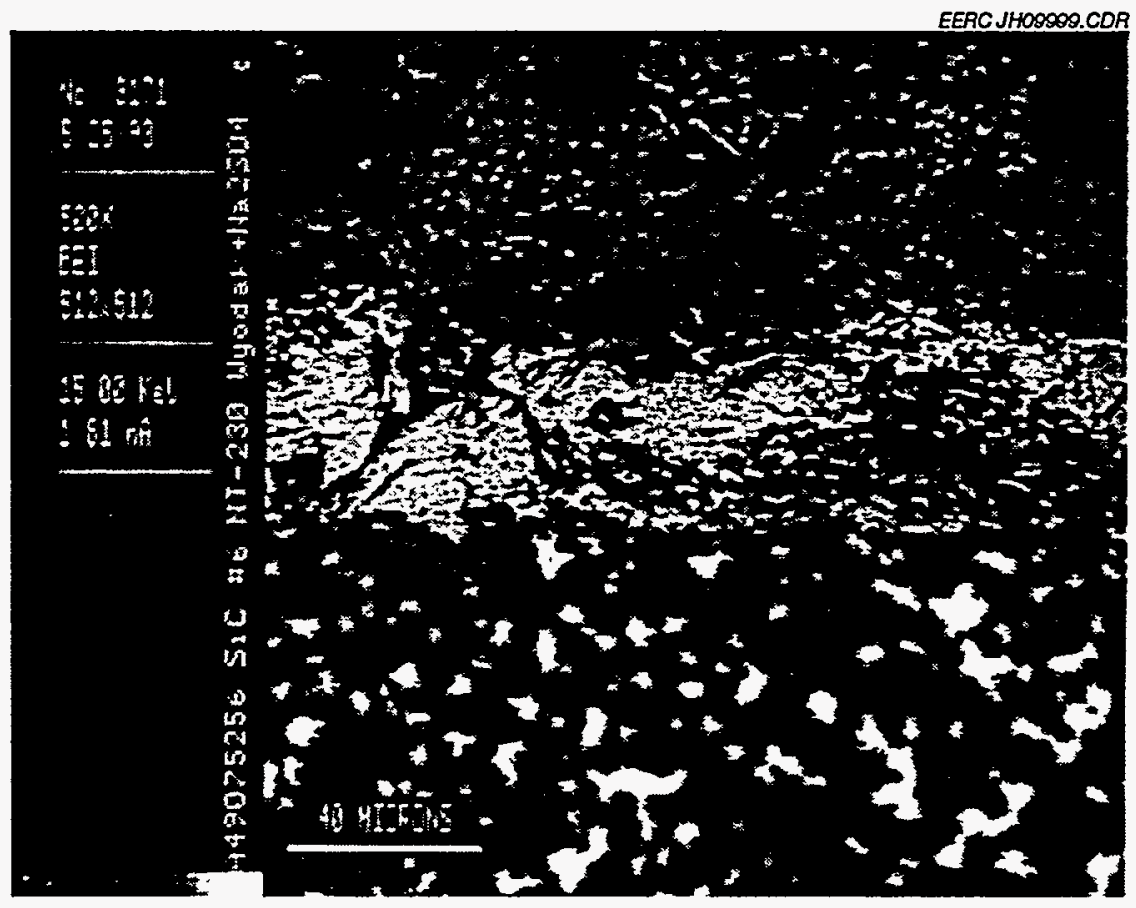

Figure 7. Scanning electron micrograph of the interface between siliconized silicon carbide (bottom) and a high-calcium ash doped with excess sodium sulfate (top) reacted at $1790^{\circ} \mathrm{F}$.

\subsection{CORROSIVE CONDITIONS IN GASIFICATION SYSTEMS}

At present, there is little literature available on the corrosion of structural ceramics in gasification systems. The elements responsible are expected to be similar to those that cause problems in combustion systems, although their chemical forms and rates of reaction may be very different. Approximately a dozen inorganic elements in the products of coal combustion affect the corrosion rates of silicon-based ceramics. These elements, including $\mathrm{H}, \mathrm{O}, \mathrm{Na}, \mathrm{Mg}, \mathrm{Al}, \mathrm{Si}, \mathrm{P}, \mathrm{S}$, $\mathrm{Cl}, \mathrm{K}, \mathrm{Ca}$, and $\mathrm{Fe}$, affect corrosion rates in three ways: as primary corrodents forming reaction products with the material, as secondary corrodents affecting the activity of the primary corrodents, or thirdly by influencing the rate of mass transfer of the primary corrodents. Although many of the elements function as more than one type of corrodent, they are listed here under what is believed to be their most active role.

The primary corrodents of silicon-based ceramics in coal-fired combustion systems include $\mathrm{O}, \mathrm{Mg}, \mathrm{Ca}$, and $\mathrm{Fe}(11-15)$. These elements form silicates or silicides that are stable in the presence of the other constituents of the ash in contact with the ceramic surface. When ash is not present, such as downstream of a filter, vapor-phase $\mathrm{Na}$ can also be a primary corrodent of silicate ceramics, forming a sodium-enriched reaction layer through which oxygen can more rapidly diffuse than through a pure silica layer (16). When ash is present, the more stable form of sodium is as a sodium aluminosilicate in the ash, rather than sodium silicate scale on the silicon carbide.

In contrast to the primary corrodents, the secondary corrodents have not been observed to form corrosion products with silica- or alumina-based ceramics. They are known, however, to 
affect the activities of some of the primary corrodents. The main elements acting in this role are $H$, $\mathrm{Al}, \mathrm{S}$, and $\mathrm{Cl}$. Hydrogen is most important in gasification conditions, because it affects the concentration of $\mathrm{O}$; in combustion conditions, it helps to form volatile hydroxides such as $\mathrm{Si}(\mathrm{OH})_{4}$ or $\mathrm{NaOH}$, which will affect corrosion rates when no other ash is present. Similarly, $\mathrm{S}$ and $\mathrm{Cl}$ affect the vapor-phase concentrations of $\mathrm{Na}_{2} \mathrm{SO}_{4}$ and $\mathrm{NaCl}$, which will affect corrosion rates when ash is not present. In addition, $\mathrm{Al}$ affects the activity of $\mathrm{Na}, \mathrm{Mg}$, and $\mathrm{Ca}$. Since these elements are more stable in an aluminosilicate phase than in a silicate corrosion product, they are less corrosive to silicate ceramics when aluminum is present in the ash.

The major role of several other elements is their effect on the transport rate of the primary corrodents. These elements include $\mathrm{Na}, \mathrm{Si}, \mathrm{P}$, and $\mathrm{K}$. Most important are their effects on the viscosity of a melt and on the rate of ion diffusion in a glass. These elements have not been observed to form corrosion products with silicon- or alumina-based ceramics in coal-fueled energy systems, except in minor roles.

Because the concentrations of many of these elements affect the activities of the primary corrodents, the surest experimental design to determine all of the interdependencies is the full factorial matrix, where the concentration of each element in the system is varied dependently on the others. However, the number of tests in such a matrix would involve $\mathrm{x}^{\mathrm{n}}$ tests, where $\mathrm{x}$ is the number of variations possible for each element, and $\mathrm{n}$ is the number of different elements. For three variations (low, medium, and high concentrations) of each of 12 elements, the number of tests is 531,441 for a single temperature and pressure condition. The numbers can be partially reduced by using a fractional factorial test matrix, but the most cost-effective way to perform corrosion tests is to base them on realistic system conditions.

The best way to obtain appropriate test conditions is to expose the material in an operating coal-fueled system. This can be expensive, since a 100 -hour pilot-scale test may cost $\$ 100,000$. As the scale of the test is reduced, so are the costs, but the accuracy of the conditions may also be compromised. To improve the accuracy of laboratory-scale test conditions and allow similar tests performed in different labs to be more comparable, the EERC has been surveying the literature and holding discussions with interested researchers and industry representatives to develop appropriate baseline test conditions. In addition, ash and slag samples are being collected from operating systems and are available from the EERC in quart or gallon quantities to materials researchers by contacting the lead author. Thermochemical equilibrium calculations are also being performed to determine approximate gas-phase concentrations of some of the elements. The conditions suggested for testing are harsh yet realistic (i.e., not accelerated) and should include all of the primary and secondary corrodents. The ceramic subsystems that are the focus of the research are hot-gas particulate filters and high-temperature heat exchangers/refractories under both combustion and gasification conditions. Conditions for testing under combustion conditions are presented in last year's report (2), so only gasification conditions will be described here.

Gasification conditions are much more difficult to simulate in the laboratory than combustion conditions because of the wide range of gas temperatures and compositions possible in the various systems and because the gas is poisonous and explosive. During gasification, coal is heated in the presence of insufficient oxygen to completely burn. Carbon monoxide and hydrogen are among the major product gases. Variations in system pressure and temperature strongly affect the concentrations of the gases in the product. Also, to keep the calorific value of the gas as high as 
possible, some gasifiers operate with pure oxygen rather than air, so that the gas is not diluted with nitrogen. This is especially true in the first IGCC systems because at the time of their design, lowBtu gas burners were not reliable. However, advances in burner design over the last decade will permit air-blown product gas to be burned efficiently in future IGCC systems. These will include the Sierra Pacific Piñon Pine Power Project and the Foster Wheeler carbonizer to be used in the Four Rivers Energy Modernization Project and in the Combustion 2000 High-Performance Power System (HiPPS).

Three main types of coal gasifiers are currently in use: entrained-flow systems such as the pressurized Shell, Texaco, and Dow gasifiers and the atmospheric Koppers-Totzek gasifier; fluidized-bed systems such as the Winkler or Kellogg-Rust-Westinghouse ${ }^{\mathrm{TI}}$ (KRW) gasifiers; and a fixed-bed system used by Lurgi. The range of measured operating temperatures and product gas compositions for these three types of gasifiers as reported by Watkinson and others are summarized in Table 2. The coals used range in rank from lignite to bituminous, and all systems shown are oxygen-blown (17).

The wide range of gasifier designs and operating conditions makes it difficult to choose one set of conditions for baseline testing of ceramic materials. As in combustion, two main subsystems should be addressed: hot-gas particle filters, where corrosion is caused by dry ash and gas, and heat exchangers/refractories where the corrosion is caused by molten slag.

\subsection{Hot-Gas Filters}

In most of the new oxygen-blown gasifier systems such as the Tampa Electric (Texaco), Wabash River (Dow), and Buggenum, Netherlands (Shell), projects, particulate cleanup will be performed in relatively cool gas at around $500^{\circ} \mathrm{F}$, so ceramic corrosion should be reduced, although early reports indicate that problems in the filter system can lead to as much as one-half of all system upsets (18). The Tampa project will include some hot-gas particulate cleanup at $1000^{\circ} \mathrm{F}$, but iron aluminide filters are proposed. Since more corrosion is expected at higher temperatures, our recommendation is to run initial ceramic particle filter gasification corrosion studies in conditions that will be experienced in the Sierra Pacific Power Company Piñon Pine Power Project fluidized-bed gasifier. The gasifier is designed as an air-blown $102-\mathrm{MWe}$ unit employing a Westinghouse ceramic particle filter system operating at as high as $1100^{\circ} \mathrm{F}$ at $300 \mathrm{psia}$. Bed temperatures are expected to reach a maximum of $1850^{\circ} \mathrm{F}$. Expected gas compositions in the filter will be approximately $25 \% \mathrm{CO}, 15 \% \mathrm{H}_{2}, 5 \% \mathrm{CO}_{2}, 5 \% \mathrm{H}_{2} \mathrm{O}$, and $50 \% \mathrm{~N}_{2}$. In general, the concentrations of the minor primary and secondary corrodents have not been measured. In addition, a hot-gas cleanup system to remove sulfur will be situated upstream of the filter system, and its effects on the minor species in the gas stream are not well understood.

In order to calculate approximate vapor concentrations of possible corrodents, the FACT program (Facility for the Analysis of Chemical Thermodynamics) developed by C.W. Bale, A.D. Pelton, and W.T. Thomson from Ecole Polytechnique de Montréal was employed. It permits the calculations of stable phases in an ash-gas system over a broad range of temperatures through the minimization of free energy for the system. The FACT code is simple to implement because only chemical formulas of possible products and the mole fractions of the elements are needed as input. 


\section{TABLE 2}

Typical Operating Conditions for the Main Types of Oxygen-Blown Gasifiers

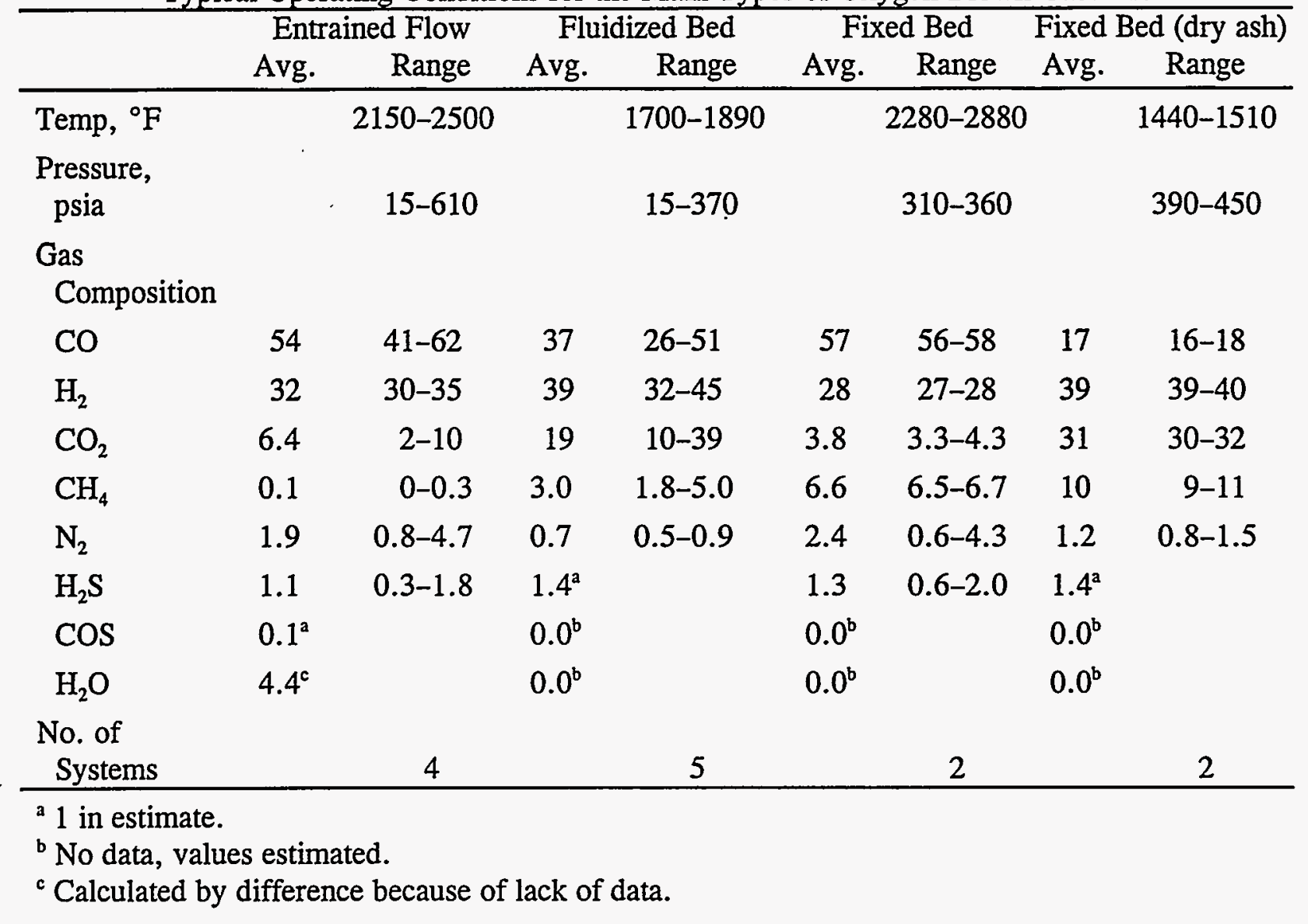

A multiple linear-regression technique estimates what stable phases are formed by minimizing errors for individual phases.

In simulating Piñon Pine gas compositions, we used a system pressure of 20 atmospheres and the design coal for the system (Utah SUFCo bituminous). These initial calculations concentrate on vapor-phase alkalis since they are expected to be among the most corrosive vapor species towards ceramics in these systems. Chlorides are expected to be the dominant vapor form of the alkalis. Unfortunately, the concentration of chlorine in the coal could not be found. Therefore the effect of the chlorine concentration in the coal on vaporization of alkalis in the bed was calculated as showing Figure 8 for a bed temperature of $1800^{\circ} \mathrm{F}$. The figure shows that the great majority of the chlorine enters the vapor phase as hydrochloric acid. Even though the concentration of sodium in the coal is considered to be relatively high, the concentration of vapor-phase sodium chloride is about three orders of magnitude less than that of the hydrochloric acid at the temperature of the bed. Most of the sodium under these conditions is present in a condensed form, primarily sodium aluminosilicates. Like sodium, only a small fraction of the potassium enters the gas phase as a chloride. However, it is more concentrated in the gas than sodium chloride even though the concentration for potassium in the coal used in these calculations is only one-tenth that of sodium. 


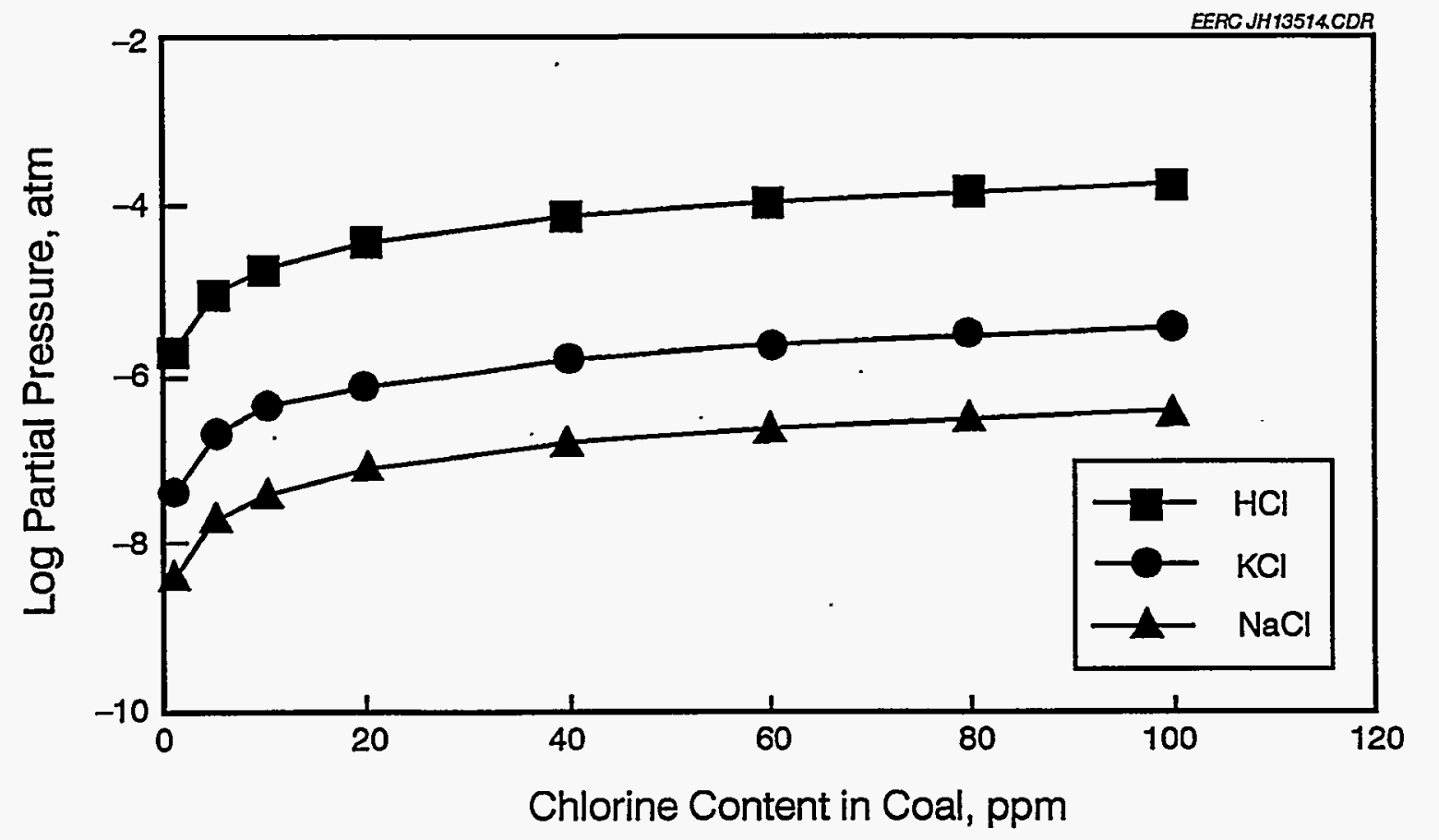

Figure 8. The calculated concentrations of major vapor-phase chloride species in the fluid bed of the Piñon Pine system as a function of the chlorine content of the coal.

Since the chlorine concentration in the coal is not known, it was assumed in calculations of vapor alkali concentrations as functions of temperature to be $100 \mathrm{ppmw}$, a relatively high figure. Table 3 shows the calculated equilibrium partial pressures of some major alkali corrodents in the gas downstream of the fluid bed. Concentrations are shown for two temperatures, $1110^{\circ} \mathrm{F}$, the approximate maximum operating temperature of the filter vessel, and $1340^{\circ} \mathrm{F}$, a temperature between that of the vessel and that of the fluid bed. The Piñon Pine system will include a hot-sulfur removal system between the fluid bed and the filter, but its effects on the concentrations of minor corrodents are not known at this time, so they were not included in these calculations. Therefore, the data in Table 3 are a better simulation of conditions when the sulfur removal system is not online.

\section{TABLE 3}

Calculated Partial Pressures of Minor Corrodent Gas Species in the Piñon Pine System

\begin{tabular}{lrr}
\hline Minor Species & $1110^{\circ} \mathrm{F}$ & $1340^{\circ} \mathrm{F}$ \\
\hline $\mathrm{H}_{2} \mathrm{~S}$ & $2200 \times 10^{-6} \mathrm{~atm}$ & $3600 \times 10^{-6} \mathrm{~atm}$ \\
$\mathrm{COS}$ & $280 \times 10^{-6} \mathrm{~atm}$ & $260 \times 10^{-6} \mathrm{~atm}$ \\
$\mathrm{HCl}$ & $76 \times 10^{-6} \mathrm{~atm}$ & $300 \times 10^{-6} \mathrm{~atm}$ \\
$\mathrm{NaCl}$ & $2.6 \times 10^{-6} \mathrm{~atm}$ & $72 \times 10^{-6} \mathrm{~atm}$ \\
$(\mathrm{NaCl})_{2}$ & $1.5 \times 10^{-6} \mathrm{~atm}$ & $34 \times 10^{-6} \mathrm{~atm}$ \\
$\mathrm{NaOH}$ & $0.00012 \times 10^{-6} \mathrm{~atm}$ & $0.018 \times 10^{-6} \mathrm{~atm}$ \\
\hline
\end{tabular}


At $1110^{\circ} \mathrm{F}$, the partial pressures of sodium species are quite low. However, at $1340^{\circ} \mathrm{F}$, a temperature between that of the filter vessel and the fluid bed, concentrations are approximately 25 times higher, indicating that the sodium species may rapidly condense as the gas cools on the way to the hot-gas filter. Since equilibrium may not be reached by the time the gas reaches the filter vessel, the concentration of sodium vapor species in the filter vessel may be much above the equilibrium concentration. Therefore, we suggest that gaseous corrosion tests under hot-gas filtration conditions be run with a gas stream saturated with $\mathrm{NaCl}$ vapor by providing an excess of sodium chloride to the system. We suggest that this be done by adding a mixture of $\mathrm{HCl}$ and $\mathrm{NaCl}$ to water that is dripped into the hot corrosion test reactor. The mixture should be added at a rate to give $\mathrm{HCl}$ and $\mathrm{NaCl}$ vapors at somewhat higher concentrations than those at equilibrium in the filter vessel. We suggest the concentrations at $1340^{\circ} \mathrm{F}(1000 \mathrm{~K})$ should be used. We acknowledge that this is a somewhat arbitrary value, but we believe that these values will provide a harsh, yet realistic concentration of corrodents, which will serve as a benchmark for further parametric tests. Since the correct partial pressures of major gas species cannot be obtained in a 1-atmosphere reactor, we suggest that they be added in concentrations equal to their concentrations in the fullscale system, although we acknowledge that other researchers prefer to use pure water vapor as the carrier gas. Until further discussions are held with corrosion researchers, we suggest gas stream concentrations for corrosion tests should be $25 \% \mathrm{CO}, 15 \% \mathrm{H}_{2}, 5 \% \mathrm{CO}_{2}, 5 \% \mathrm{H}_{2} \mathrm{O}, 300 \mathrm{ppm} \mathrm{HCl}$, and $75 \mathrm{ppm} \mathrm{NaCl}$, with a balance of nitrogen. We suggest that the benchmark tests be run at $1100^{\circ} \mathrm{F}$, with other, lower temperatures added in parametric tests.

In addition to vapor species, the ash may also corrode system components. The ash used for corrosion tests should be approximately at equilibrium at the start of the tests to prevent any unrealistic corrosion reactions from occurring as the ash attempts to reach equilibrium test conditions. Unfortunately, the Piñon Pine system is not expected to operate under standard conditions to supply ash to corrosion researchers until sometime in 1997. Therefore, the EERC is making available to corrosion researchers ash collected from the filter vessel of the EERC pilotscale transport reactor development unit (TRDU) from a test run performed in April 1996. The system is designed to operate under conditions similar to those at Piñon Pine, although a coal from the Belle Ayr mine, Powder River Basin, Wyoming, was used for the TRDU tests rather than the Utah coal that is the design coal for the Piñon Pine system. The Belle Ayr ash has the advantage for corrosion tests in that it is well characterized, is available as a standard ash free of charge, and will also be used at the Southern Company Services Wilsonville hot-gas filter test facility, which will also be operating fully by 1997 . The composition of the TRDU ash that is now available is given in Tables 4-6.

\subsection{Molten Slag Corrosion}

At the high operating temperatures to which some heat exchangers and refractories will be exposed, the ash will be very sticky, if not molten, and will coat the subsystems and prevent direct gaseous corrosion of the materials. However, the composition of the gas in the corrosion reactor will still play an important role in the test, since the atmosphere directly affects the viscosity and therefore the erosiveness and corrosiveness of the slag. Figure 9 shows the viscosity versus temperature curves of a slag prepared from ash made by burning coal in the laboratory. The coal is from the Rochelle mine of the Wyoming Powder River Basin and is considered to have a relatively high calcium content. The three curves show the changes in viscosity caused by changes in the surrounding atmosphere. The fundamental reasons for the changes in viscosity are not completely 
TABLE 4

TRDU Filter Ash Ultimate-Proximate Analysis

\begin{tabular}{lc}
\hline Ultimate Analysis & As-Recd., \% \\
\hline Hydrogen & 0.28 \\
Carbon & 1.26 \\
Nitrogen & 0.14 \\
Sulfur & 0.38 \\
Oxygen, ind. & 3.48 \\
Ash & 94.48 \\
\hline Proximate Analysis & As-Recd., \% \\
\hline Moisture & 0.75 \\
Volatile Matter & 4.72 \\
Fixed Carbon, ind. & 0.06 \\
Ash & 94.48 \\
\hline
\end{tabular}

TABLE 5

TRDU Filter Ash Composition

\begin{tabular}{lrcc}
\hline $\mathrm{SiO}_{2}$ & 53.7 & $\mathrm{CaO}$ & 13.1 \\
$\mathrm{Al}_{2} \mathrm{O}_{3}$ & 21.7 & $\mathrm{MgO}$ & 7.0 \\
$\mathrm{Fe}_{2} \mathrm{O}_{3}$ & 1.5 & $\mathrm{Na}_{2} \mathrm{O}$ & 0.6 \\
$\mathrm{TiO}_{2}$ & 0.8 & $\mathrm{~K}_{2} \mathrm{O}$ & 0.0 \\
$\mathrm{P}_{2} \mathrm{O}_{5}$ & 0.7 & $\mathrm{SO}_{3}$ & 1.1 \\
\hline
\end{tabular}

clear, but are believed to be caused by the breakup of O-Si bonds and the creation of nonbridging hydroxyl groups, which will lower viscosity (reducing gas), but may also act as a mineralizer and increase the temperature at which crystallization occurs (air + water). These effects are especially strong for the more basic coal slags because water vapor is usually more soluble in more basic silicate glasses, even dissolving in a molecular form (19). We suggest an overall gas composition for slag corrosion tests of approximately $30 \% \mathrm{H}_{2}, 45 \% \mathrm{CO}$, and $25 \% \mathrm{CO}_{2}$ to which $10 \%$ water vapor is added. Because of equilibrium reactions at this temperature, we have calculated that the concentrations of $\mathrm{CO}$ may reach as high as $49 \%, \mathrm{H}_{2} \mathrm{O}$ as high as $18 \%, \mathrm{CO}_{2}$ as low as $13 \%$, and $\mathrm{H}_{2}$ 
TABLE 6

TRDU Filter Ash Crystalline Composition

\begin{tabular}{|c|c|}
\hline Minor Phase(s) & Nominal Composition(s) \\
\hline Melilite & $\mathrm{Ca}_{2}(\mathrm{Mg}, \mathrm{Al})(\mathrm{Al}, \mathrm{Si})_{2} \mathrm{O}_{7}$ \\
\hline Periclase & $\mathrm{MgO}$ \\
\hline Quartz & $\mathrm{SiO}_{2}$ \\
\hline Potassium Aluminum Silicate & $\mathrm{K}_{48.2} \mathrm{Al}_{48.2} \mathrm{Si}_{143.8} \mathrm{O}_{384}$ \\
\hline Plagioclase & $(\mathrm{Ca}, \mathrm{Na})(\mathrm{Al}, \mathrm{Si})_{4} \mathrm{O}_{8}$ \\
\hline Gismondine (zeolite) & $\mathrm{CaAl}_{2} \mathrm{Si}_{2} \mathrm{O}_{8} \cdot 4 \mathrm{H}_{2} \mathrm{O}$ \\
\hline Gmelinite (zeolite) & $\mathrm{Na}_{2} \mathrm{Al}_{2} \mathrm{Si}_{4} \mathrm{O}_{12} \cdot 6 \mathrm{H}_{2} \mathrm{O}$ \\
\hline Ferrite Spinel & $(\mathrm{Mg}, \mathrm{Fe})(\mathrm{Fe}, \mathrm{Al})_{2} \mathrm{O}_{4}$ \\
\hline
\end{tabular}

as low as $20 \%$ at $1400^{\circ} \mathrm{C}$. $\mathrm{SO}_{2}$ and $\mathrm{H}_{2} \mathrm{~S}$ may cause changes in melt structure similar to those caused by water vapor, but because they are present in much lower concentrations, the sulfur-containing gases are expected to have a lesser effect, although this assumption must still be tested.

In addition to use of the correct atmosphere in slag corrosion tests, the slag should be in a relatively stable thermodynamic form at the beginning of the test. This can be best assured by

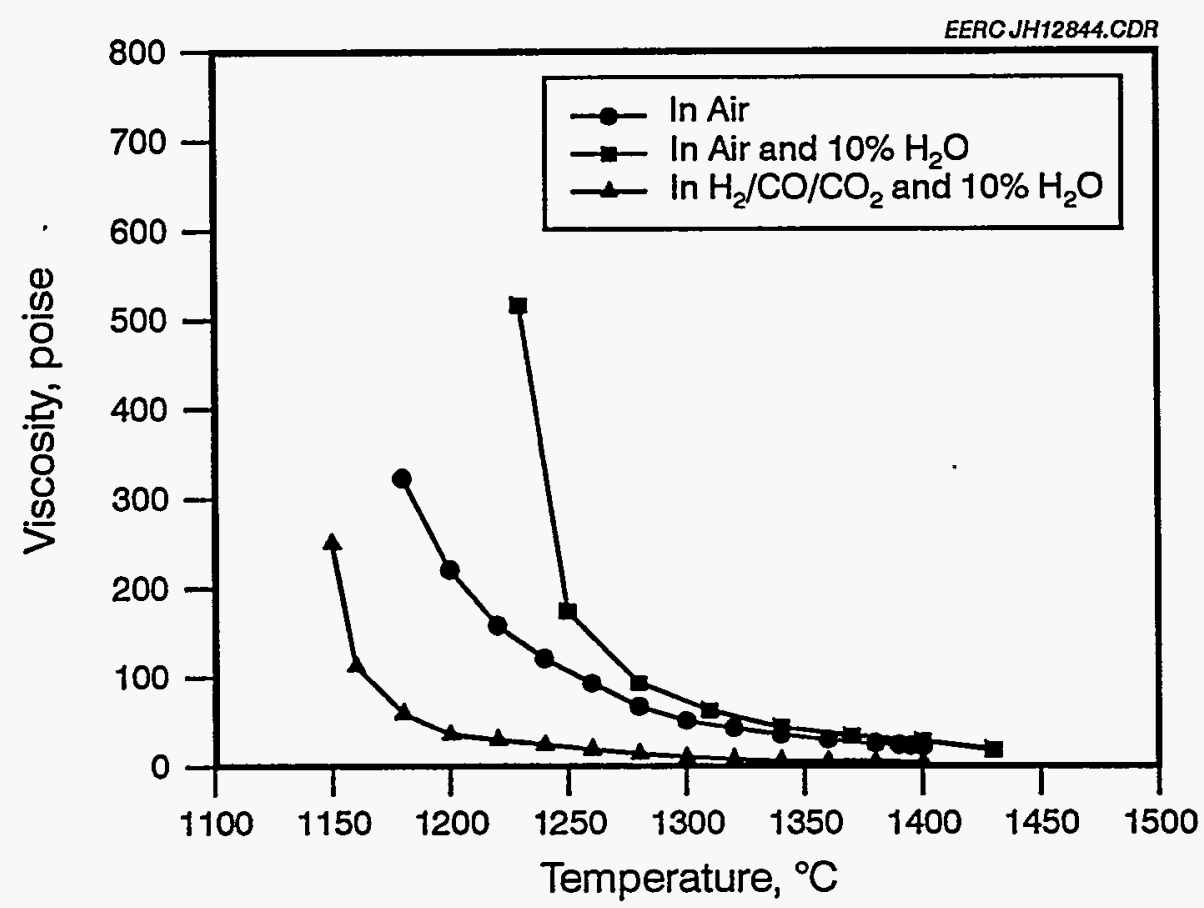

Figure 9. Viscosity versus temperature for Rochelle mine coal ash slag under three atmospheres. 
producing the slag under realistic operating conditions or by collecting the slag from a large-scale operating facility.

Unfortunately, most gasifier manufacturers and operators are very secretive about their operations, so it can be very difficult to obtain gasifier slag. However, the EERC has available coal slag donated for corrosion testing by three power plants burning economically important coals. The slags are produced in boilers fired with cyclone burners and are therefore in a mildly reduced state. High-calcium subbituminous coal slag was provided by the Northern States Power Company Riverside Plant, which was burning a coal from the Powder River Basin in Wyoming: Illinois . No. 6 bituminous coal slag was provided by the Central Illinois Public Service Coffeen Plant. Analysis of the Coffeen slag showed abnormally high calcium concentrations owing to limestone additions to reduce slag viscosity, so another drum of more "pure" Illinois No. 6 slag was obtained from the Illinois Power Company Baldwin Plant. The compositions of the slags as well as the TRDU ash that can be used for corrosion tests at lower temperatures are shown in Table 7. Suggested temperatures for high-temperature slag corrosion testing are $2000^{\circ} \mathrm{F}$ for sintered ash conditions, $2300^{\circ} \mathrm{F}$ for viscous molten ash, and $2600^{\circ} \mathrm{F}$ for running ash. The slag layer thickness should be approximately 1 millimeter at $2600^{\circ} \mathrm{F}$ and 5 millimeters at $2300^{\circ} \mathrm{F}$ to ensure appropriate gas transport through the slag. The slag should be replenished often enough that it does not become overly concentrated with corrosion products.

\subsection{SUMMARY}

For a given temperature, the rate of corrosion of ceramic materials in advanced coal-fired energy systems is affected by the composition of the gas and condensed species in contact with the material. Approximately 12 elements affect the corrosion rates of silicon- and alumina-based ceramics in coal-fueled systems: $\mathrm{O}, \mathrm{Mg}, \mathrm{Ca}, \mathrm{Fe}$, and $\mathrm{Na}$ (when no ash is present) are primary corrodents in that they have been observed to form corrosion products with silicon carbides. Secondary corrodents- $\mathrm{H}, \mathrm{Al}, \mathrm{S}$, and $\mathrm{Cl}$-have not been observed to form corrosion products but do affect the activity of the primary corrodents. The other major elements, including $\mathrm{Na}, \mathrm{Si}, \mathrm{P}$, and

\section{TABLE 7}

Chemical Compositions of Standard Ashes, wt\%

\begin{tabular}{lcccc}
\hline Oxide & TRDU Ash & Riverside Slag & Coffeen Slag & Baldwin Slag \\
\hline $\mathrm{SiO}_{2}$ & 53.7 & 47.0 & 52.5 & 53.4 \\
$\mathrm{Al}_{2} \mathrm{O}_{3}$ & 21.7 & 18.6 & 16.3 & 18.6 \\
$\mathrm{Fe}_{2} \mathrm{O}_{3}$ & 1.5 & 5.3 & 13.5 & 17.6 \\
$\mathrm{TiO}_{2}$ & 0.8 & 1.4 & 0.7 & 0.7 \\
$\mathrm{P}_{2} \mathrm{O}_{5}$ & 0.7 & 0.6 & 0.2 & 0 \\
$\mathrm{CaO}$ & 13.1 & 19.7 & 13.1 & 7.1 \\
$\mathrm{MgO}$ & 7.0 & 5.7 & 1.2 & 0.9 \\
$\mathrm{Na}_{2} \mathrm{O}$ & 0.6 & 0.9 & 0.8 & 0.0 \\
$\mathrm{~K}_{2} \mathrm{O}$ & 0.0 & 0.3 & 1.6 & 1.7 \\
$\mathrm{SO}_{3}$ & 1.1 & 0.3 & 0.1 & 0.0 \\
\hline
\end{tabular}


$\mathrm{K}$, affect the rate of transport of the primary corrodents by affecting slag viscosity and ion mobility. In general, very little work has been done under reducing conditions, so the primary and secondary corrodents in gasifier systems are not well understood at this time.

To improve the accuracy of laboratory-scale combustion test conditions and assure comparability between testing groups, the EERC has assembled 55-gallon drums of coal ash and slag from large-scale coal-fueled systems that are approximately in equilibrium for mildly reducing conditions. For hot-gas filter testing, ash from the EERC TRDU hot-gas filter is available. The suggested total gas stream concentrations for these tests should be $25 \% \mathrm{CO}, 15 \% \mathrm{H}_{2}, 5 \% \mathrm{CO}_{2}, 5 \%$ $\mathrm{H}_{2} \mathrm{O}, 300 \mathrm{ppm} \mathrm{HCl}$, and $75 \mathrm{ppm} \mathrm{NaCl}$, with a balance of nitrogen. We suggest that the benchmark tests be run at $1100^{\circ} \mathrm{F}$, with other lower temperatures added in parametric tests.

To simulate the type of ash that will strike a high-temperature heat exchanger in a gasification system upstream of ash removal devices, slags produced under slightly reducing conditions are available from utility cyclone-fired boilers. Suggested initial conditions for slag testing are $2000^{\circ} \mathrm{F}$ for sintered ash conditions, $2300^{\circ} \mathrm{F}$ for viscous molten ash, and $2600^{\circ} \mathrm{F}$ for runny molten ash. We suggest an overall gas composition of approximately $30 \% \mathrm{H}_{2}, 45 \% \mathrm{CO}$, and $25 \% \mathrm{CO}_{2}$ to which $10 \%$ water vapor is added. To ensure appropriate gas transport, the slag layer thickness in a static test should be approximately 1 millimeter for runny slag and 5 millimeters for viscous slags. The slag should be changed often enough to prevent it from becoming overiy concentrated in corrosion products, since in a commercial system, the slag will be constantly replenished.

\subsection{REFERENCES}

1. Hurley, J.P.; Nowok, J.W. "Conditions for Testing the Corrosion Rates of Ceramics in Coal Gasification Systems" In Proceedings of the 10th Annual Conference on Fossil Energy Materials; ORNL/FMP-96/1, 1996.

2. Hurley, J.P. "Support Services for Ceramic Fiber-Ceramic Matrix Composites," ORNL/Sub/94-SS112/01, 1995.

3. Combustion Engineering Inc. Combustion, 3rd ed.; Rand McNally: Chicago, 1981; pp 35-57.

4. Hurley, J.P.; Schobert, H.H. “Ash Formation During Pulverized Subbituminous Coal Combustion, 1. Characterization of Coals and Inorganic Transformations During Early Stages of Burnout," Energy \& Fuels 1992, 6 (1), 47-58.

5. Hurley, J.P.; Schobert, H.H. “Ash Formation During Pulverized Subbituminous Coal Combustion, 2. Inorganic Transformations During Middle and Late Stages of Burnout," Energy \& Fuels 1993, 7, 542-553.

6. Walsh, P.M.; Sayre, A.N.; Loehden, D.O.; Monroe, L.S.; Beér, J.M.; Sarofim, A.F. Prog. Energy Combust. Sci. 1990, 16, 327-346. 
7. Benson, S.A.; Jones, M.L.; Harb, J.H. "Ash Formation and Deposition," In Fundamentals of Coal Combustion for Clean and Efficient Use; Smoot, D., Ed.; Elsevier: Amsterdam, 1993; 299.

8. Baxter, L.L.; DeSollar, R.W. Fuel 1993, 72, 1411.

9. Wibberley, L.J.; Wall, T.F. Fuel 1982, 61, 93-99.

10. Hurley, J.P.; Benson, S.A.; Erickson, T.A.; Allan, S.E.; Bieber, J. "Project Calcium Final Report," DOE/MC/10637-3292, 1995.

11. Strobel, T.M.; Hurley, J.P.; Senior, C.L.; Holowczak, J.E. “Coal Slag Corrosion of Silicon Carbide-Based Ceramics in a Combustion Environment," In Proceedings of the Symposium on Silicon Carbide-Based Structural Ceramics; American Ceramic Society PAC RIM Meeting, Honolulu, HI, Nov. 7-10, 1993; pp 327-334.

12. Senior, C.L.; Moniz, G.A.; Hurley, J.P.; Strobel, T.M. "Corrosion of Silicon Carbides by Ash and Vapor in a Coal Combustion Environment," In Proceedings of the Symposium on Silicon Carbide-Based Structural Ceramics; American Ceramic Society PAC RIM Meeting, Honolulu, HI, Nov. 7-10, 1993; pp 335-342.

13. Ferber, M.K.; Tennery, V.J. "Behavior of Tubular Ceramic Heat Exchanger Materials in Acidic Coal Ash from Coal-Oil Mixture Combustion,” Ceram. Bull. 1983, 62 (2), 236-243.

14. Ferber, M.K.; Tennery, V.J. "Behavior of Tubular Ceramic Heat Exchanger Materials in Basic Coal Ash from Coal-Oil Mixture Combustion," Ceram. Bull. 1984, 63 (7), 898-904.

15. Strobel, T.M.; Hurley, J.P.; Breder, K. J.; Holowczak, E. "Coal Slag Corrosion and Strength Degradation of Silicon Carbide-Alumina Composites," In Ceramics Engineering \& Science Proceedings 1994, 15 (4), 579-586.

16. Zheng, Z.; Tressler, R.E.; Spear, K.E. "A Comparison of the Oxidation of Sodium Implanted CVD $\mathrm{Si}_{3} \mathrm{~N}_{4}$ with the Oxidation of Sodium-Implanted SiC Crystals," Corrosion Science 1992, 33 (4), 569-580.

17. Watkinson, A.P.; Lucas, J.P.; Lim, C.J. "A Prediction of Performance of Commercial Coal Gasifiers," Fuel 1991, 70, 519-527.

18. Troxclair, E.J.; Amick, P.; Breton, D.L.; Schulz, J. "Wabash River Coal Gasification Repowering Project - Early Commercial Operating Experience," Presented at the 13th Annual Pittsburgh Coal Conference, Sep. 1996.

19. Shelby, J.E. Handbook of Gas Diffusion in Solids and Melts; 1996; p 223. 